\title{
INITIAL THOUGHTS OF COVID-19 UNEXPECTED CONSEQUENCES FOR TOURISM
}

\author{
Arabela Briciu ${ }^{1}$ \\ Victor-Alexandru Briciu ${ }^{2}$ \\ Andrea-Eniko Csiki ${ }^{3}$
}

DOI: https://doi.org/10.31410/ITEMA.S.P.2020.23

\begin{abstract}
This paper addresses some initial scientific points of view about the new topic regarding the Coronavirus influence known until now and the objective is to reveal some unexpected consequences of the virus for tourism. The research aims to present the impact that the virus had on travel blogs from Romania. Because the tourism sector has been and still is affected due to this virus we decided to analyse travel blogs from a comparative perspective, more precisely, the articles posted in 2019, in March-May, and those of this year. The novelty element that the paper brings is represented by the impact of the virus determined on the content generated by travel bloggers, and in Romanian research, there is a small number of such studies, focused on travel blogs.
\end{abstract}

Keywords: Travel, Tourism, Virus, Impact, Consequences, Opportunities, Blogs.

\section{INTRODUCTION}

$\mathrm{T}$

Tourism is one of the most important and complex phenomena of human activity attested since ancient times. The inclusion of tourism among other sectors of the economy can be explained primarily by economic and cultural intensification, relations between countries in the world through accelerated urbanization, increasing the number of employees, increasing materials, welfare and cultural level of the population and its level of computerization and digitization, through modernization, and rapid development of transport and telecommunications routes (Tălămbuță, 2018, p. 34).

The study of the phenomenon of tourism from several points of view has a strong link to travel and growth or intensification and development in all fields. There is also a difference between the terms "visitor" and "tourist", so that "a visitor is any person who moves through a territory, backpacker or temporary visitor who makes a less than a 24-hour visit, while the tourist is the one that spends the night in another place than his/her home" (Tudor, 2012, p. 162).

Another perspective of tourism is by taking into consideration the branding aspect, because "the general supposition that a 'destination' brand denotes the tourism dimension of a place is widely supported" (Hanna and Rowley, 2008, p. 64). Also, branding is a concept of "marketing and branding of a place in terms of its leisure and tourism" (Maheshwari and

Transilvania University of Brașov, Faculty of Sociology and Communication, Department of Social Sciences and Comunication, Eroilor Blvd., no. 25, Brasov City, Brasov County, Romania

2 Transilvania University of Brașov, Faculty of Sociology and Communication, Department of Social Sciences and Comunication, Eroilor Blvd., no. 25, Brasov City, Brasov County, Romania,

3 M.A. Student in Human Resources Management and Development, Transilvania University of Brașov, Romania 
Vandewalle, 2008, p. 4) or another more nuanced characterization suggests that: "It is in the context of tourism that a geographic location is (or includes) a destination brand" (2006, pp. 276-277).

It must be stated the different approach and meaning of the terms "travel" and "tourism" because most researchers distinguish between them. "Travel is associated with authenticity, adventure, and spontaneity. Tourism, on the other hand, has the less desirable connotations of being planned and superficial" (Azariah, 2017, p. 1) and marketed. This view is well stated in the observation of the American historian Daniel J. Boorstin: "The traveller was active; he went strenuously in search of people, of adventure, of experience. The tourist is passive; he expects interesting things to happen to him. He goes 'sight-seeing'..." (Azariah, 2017, p. 1).

Until the emergence of new technologies and means of communication, tourists used or adopted the practice of "journaling" (Pudliner, 2007, p. 46) "as a popular means of recording their own travel experiences; sharing their feelings and impressions about the places they visited" (Wang and Morais, 2014, p. 239). As mass tourism became the dominating industry, "the development of technology and the emergence of the Internet have made it possible and popular to post and publish personal travel experiences on weblogs" (Buhalis, 2003) and it became "an individual act" (Wang and Morais, 2014, p. 240); alongside modern and contemporary technologies, "tourism and photography are inextricably linked to each other, so much so that they are described as 'modern twins'" (Azariah, 2017, p. 131).

All in all, it can be stated that without tourists there would be no tourism. The tourism industry refers to "the businesses and organizations that help to promote the tourism product" (Wang, 2011, p. 2).

\section{APPEARANCE OF CORONAVIRUS DISEASE}

It's not the first time in human history that a Coronavirus "has taken the public health community by surprise. Most will remember the severe acute respiratory syndrome (SARS) coronavirus outbreak of the early 2000s, but many may not realize that another novel coronavirus Middle Eastern respiratory syndrome (MERS) is currently circulating in parts of the world" (Jamal and Budke, 2020, p. 182).

As it is known to this date, Coronavirus 2019 (COVID-19) is "an infectious disease caused by severe acute respiratory syndrome Coronavirus 2 (SARS-CoV-2)" (Bakar and Rosbi, 2020, p. 189). The new outbreak of Coronavirus (COVID-19) "was first reported in Wuhan, China and spread rapidly worldwide via human-to-human transmission" (Wen, Wang, Kozak, Liu, and Hou, 2020, p. 1).

The rate at which the COVID-19 virus was transmitted reached the globe, Europe soon became the epicenter of the pandemic, but afterwards has been overtaken by the United States (Johns Hopkins University, 2020). COVID-19 spreads "when a person touches a surface or object that has the virus on it, then touches their eyes, nose or mouth. COVID-19 virus can live up to 72 hours" (Bakar and Rosbi, 2020, p. 189).

As this virus reaches and gains almost all human-inhabited territories, specialists and scientists are working day and night to try to understand, control and annihilate it. "Areas of specialisation include anatomy, physiology, and pathology along with biochemistry, immunology, virology, microbiology, molecular biology, genetics, preventive medicine, and 
public health. As the world comes together to fight COVID-19, professionals in these sciences are facing great public pressure to research and develop vaccinations and medications to save lives" (Wen et al., 2020, p. 1).

Tourism is among the first and most severely affected industries by the COVID-19 virus. Recovery in tourism is "expected to start from domestic tourism and continue with recovered destinations which were usually first affected (e.g. Far East, Europe than Americas)" (Cetin, 2020 , p. 1). The tourism industry could also face new conditions imposed for international travel. For example, only people under the age of 25 could be allowed, proven to have a lower rate of COVID-19 infection, or agree to spend 14 days in quarantine on arrival (Cetin, 2020).

Regardless of the scenario, tourism will see a sharp and long-term decline, as this pandemic will have or determine major economic effects. Purchasing power will decrease significantly, so online systems begin to take control in all areas (Kirant Yozcu and Cetin, 2019).

Table 1. Positive and negative impact of COVID-19 virus on tourism

\begin{tabular}{|c|c|}
\hline Positive Impact & Negative Impact \\
\hline $\begin{array}{l}\text { Increased rate of tourist flow to domestic } \\
\text { destinations due to lockdown and imposed } \\
\text { limitations }\end{array}$ & $\begin{array}{l}\text { Decreasing the purchasing power of } \\
\text { tourists }\end{array}$ \\
\hline $\begin{array}{l}\text { The emergence of new tourist destinations } \\
\text { and the change of the image of the } \\
\text { destinations }\end{array}$ & Tourist psychosis \\
\hline $\begin{array}{l}\text { Sudden increase in family outings to nature- } \\
\text { based tourism }\end{array}$ & Giving up long trips/destinations \\
\hline Increasing rural tourism, agrotourism & Racism and cultural differentiation \\
\hline $\begin{array}{l}\text { Improved standards in health, travel, } \\
\text { communication, shopping, and sanitation }\end{array}$ & Visibly slow exports \\
\hline $\begin{array}{l}\text { Promoting organic products and changing } \\
\text { the eating habits of tourists and visitors }\end{array}$ & $\begin{array}{l}\text { Job loss in the unorganized tourism and } \\
\text { alternative accommodation sector }\end{array}$ \\
\hline $\begin{array}{l}\text { Tourism support - more awareness of nature, } \\
\text { culture and ecology }\end{array}$ & $\begin{array}{l}\text { Negative balance of payments due to the } \\
\text { increase in domestic tourism }\end{array}$ \\
\hline Restrictions on trade of wild animals & \\
\hline $\begin{array}{l}\text { Accelerating the sense of biodiversity } \\
\text { conservation }\end{array}$ & \\
\hline Stimulating domestic/national tourism & \\
\hline
\end{tabular}

Source: Chiranjib, 2020, p. 2

And yet, the COVID-19 pandemic determined a positive and a negative impact on tourism, which, of course, varies from country to country (see Table 1 above). The Coronavirus Crisis has brought more innovation and positive impact "through various untapped opportunities" (Chiranjib, 2020, p. 4). Thus, the tourism and the hotel industry could see more domestic tourists than international tourists in the next two years. A segment of luxury and first-class hotels will suffer due to the decline of international customers. Large travel agencies and airlines will have "to cut their revenue index by 30-40\% instead of increasing" (Chiranjib, 2020, p. 4). 


\section{UNEXPECTED CONSEQUENCES OF THE PANDEMIC FOR TOURISM}

The increase in consumption in the tourism sector has been determined by various factors over the years, especially "the growth of new technologies, new lifestyle trends associated with growing global prosperity and the advent of low-cost airlines, which made international travel affordable for the masses" (Folinas and Metaxas, 2020, p. 366).

In the 21st century, "during this period of acute pressure" (Briciu and Briciu, 2020b, p. 23) two important factors influence the development of tourism: climate change and global health emergencies.

The COVID-19 pandemic "has resulted in mass production shutdowns and supply chain disruptions causing global ripple effects across all economic sectors in a manner that was never expected" (Oruonye and Ahmed, 2020, p. 33). The tourism industry is in a major crisis and will face unprecedented threats. Tourism has shown how quickly changes can happen in a few months, as "the industry has collapsed all over the world" (Sheresheva, 2020, p. 73).

The authors Gössling, Scott, and Hall (2020) noted that global tourism has been exposed to a wide range of crises in the last years, which they called "major disruptive events" (p. 3). However, "there is much evidence that the impact and recovery from the COVID-19 pandemic will be unprecedented" (Gössling, Scott, and Hall, 2020, p. 3).

Tourists have played and continue to play a significant role in bringing new cases of COVID19 virus to other countries, with continuous transmission confirmed from person to person and also transmission from asymptomatic people, which is why the measure has been taken to close the borders, and the tourism industry to be severely affected (Wen et al., 2020).

However, the representatives of the World Tourism Organization (UNWTO) have launched an awareness campaign to communicate solidarity and respect, care for the environment, continuing learning, and generating new opportunities for all. These are the core values of tourism supported by the World Tourism Organization and represent the main objectives of the \#TravelTomorrow campaign (UNWTO, 2020). Be part of the \#TravelTomorrow transformation has become this organization's response to the current crisis, highlighting the attractive values of tourism. This online campaign generated an important impact through social media and is being "embraced" by a growing number of countries, the \#TravelTomorrow amplifying the voice of tourism, which is united in the face of this global and unprecedented challenge (UNWTO, 2020).

\section{NEW MEDIA, BLOGS AND TRAVEL BLOGS}

The new mediums of communication are commonly referred to 'new media' (and include social networks, websites, blogs, video games, social media, etc.) (Briciu, Briciu and Găitan, 2019 , p. 584). Weblogs offer today a wide range of materials related to health, news, tourist experiences, etc., as "a website owned by an entity (a person, a group of people, a company, etc.) where articles are posted on specific topics, and people who visit the blog can add comments" (Briciu and Briciu, 2021, p. 2611).

Blogs are a means of communication on the WWW that make it easier for people to communicate freely (Gala, 2004) and can be defined as "a website that contains an online 
personal journal with reflections, comments, and often hyperlinks provided by the writer" (Kelleher and Miller, 2006, p. 396).

Bloggers can upload videos, photos, and information from their area of interest; there are general blogs, but also thematic blogs according to users' preferences (travel blogs, cooking blogs, fashion, professional development, etc.) From this point of view, travel blogs are online journals and stories designed to provide information and engage the reader in the travel experience.

\section{RESEARCH}

This study focuses on Romanian travel blogs as a means of communication between bloggers and consumers during the pandemic caused by the COVID-19 virus. Blogs have the advantage of transmitting transparent information to the public, to achieve certain objectives, including promoting tourism (Briciu and Briciu, 2020a) and disseminating travel experiences. To see how the content generated by the posted articles has changed, how travel bloggers have adapted during this period of pandemics, we developed a comparison situation between March, April, and May of 2019, respectively the same months of 2020.

The sample was defined by the best Romanian travel and tourism blogs from 2019 according to the ranking published by Biz Magazine in collaboration with Zelist, which annually deliver "Digital Report", a synthesis of the online environment in Romania (Săndulescu, 2019). Regarding the selection criteria, we used the condition of at least five posts within a year and with at least three articles published in the last three months of the analysed period: January 1 - December 31, 2018, so the final sample consists of 14 blogs. The analysis focused on: (1) the visual content, (2) the written content, and (3) the tags most commonly found on travel blogs.

Discussing the results for the first dimension: "Visual Content of Travel Blogs", sponsorships (as a category) were more frequent in 2019 than in 2020, because the COVID-19 virus also influenced this sector, as bloggers could test and provide feedback on products or services last year. Photos related to holidays and travel were more common in 2019, but what we could determine is that in 2020 bloggers posted more photos from previous holidays or different destinations from the previous year. The photos from the category of airlines played an important role during this year because the most common and important topics for tourists were the ones related to planes.

Regarding the result of the second analysed dimension: "Written Content of Travel Blogs", the main categories from 2020 were COVID-19, tourism, other topics, and from 2019: sponsorships, other topics, travel, tips, events. In the COVID-19 category, most articles addressed the subject of airlines, and the fewest were represented by health insurance. In the tourism category, the most approached topic was about the guides for visiting some destinations or attractions, how global tourism will recover, etc. The most common subject in other topics category was about online events, such as museums and galleries that offer virtual tours. The category of sponsored products or services included five main topics: care/ beauty products and online networks, technical or travel equipment, different stores, and promoted destinations.

"Use of Tags on Travel Blogs", the third dimension was characterised by the subject of COVID-19 (126 tags), and destinations from 2019 (108 tags). These tags best illustrate the topics covered by the selected travel blogs. The news category in 2019 includes 45 tags, and in 
2020 this topic is all about COVID-19. The labels regarding the destinations in Romania for 2019 are 30 in number, and for 2020 they are 38 in number, and for airlines in 2019 we found 9 tags, and in 2020, 45 tags.

\section{CONCLUSION}

The objectives initially set were achieved following the interpretation of the results, so that the influence of Coronavirus was identified by the content of the articles posted on the Romanian travel blogs. The global impact of Coronavirus has generated useful information for consumers. Another important thing is that travel bloggers were able to provide quality content for their followers and have turned this inconvenience into an advantage. Travel bloggers generated content on blogs, regardless of the existence of the COVID-19 virus, and they continued to post and adapt the content of articles from the perspective of the impact of the virus. Thus, they generated relevant information to consumers, attracting them and managing their loyalty through articles posted on travel blogs.

\section{REFERENCES}

Azariah, D. R. (2017). Tourism, travel, and blogging: A discursive analysis of online travel narratives. London: Routledge. https://doi.org/10.4324/9781315550688

Bakar, N. A., \& Rosbi, S. (2020). Effect of Coronavirus disease (COVID-19) to tourism industry. International Journal of Advanced Engineering Research and Science, 7, 189193. https://dx.doi.org/10.22161/ijaers.74.23

Briciu, A., \& Briciu, V. A. (2020a). Participatory Culture and Tourist Experience: Promoting Destinations Through YouTube. In A. Kavoura, E. Kefallonitis \& P. Theodoridis (Eds.), Strategic Innovative Marketing and Tourism. Springer Proceedings in Business and Economics (pp. 425-433). Cham: Springer. https://doi.org/10.1007/978-3-030-36126-6_47

Briciu, V. A., \& Briciu, A. (2021). Social Media and Organizational Communication. In M. Khosrow-Pour D.B.A. (Ed.), Encyclopedia of Organizational Knowledge, Administration, and Technology (pp. 2609-2624). Hershey, PA: IGI Global. http://doi:10.4018/978-1-7998-3473-1.ch180

Briciu, V.-A., \& Briciu, A. (2020b). COVID-19 Influence and Future Perspectives of Artificial Intelligence on the Labour Market. BRAIN. Broad Research in Artificial Intelligence and Neuroscience, 11(2Sup1), 21-28. https://doi.org/10.18662/brain/11.2Sup1/90

Briciu, V.-A., Briciu, A., \& Găitan, Ș.-M. (2019). The Image Management Strategy through Social Networks. An Analysis of the Banking Environment in Romania. International Scientific Conference EMAN - Economics \& Management: How to Cope with Disrupted Times - Conference Proceedings (pp. 583-588), Association of Economists and Managers of the Balkans, Belgrade, Serbia. 10.31410/EMAN.2019.583

Buhalis, D. (2003). eTourism: information technology for strategic tourism management. London: Prentice Hall

Cetin, G. (2020). Editorial: Impact of Covid-19 on Tourism Industry. Journal of Tourismology, $6 \quad(1), \quad 1-3 . \quad$ Retrieved from https://dergipark.org.tr/en/pub/iuturizmoloji/issue/52515/772491

Chiranjib, K. C. (2020). Corona (COVID-19) and tourism: more opportunities in the aftermath of the lockdown. Retrieved from Research Gate. doi:10.13140/RG.2.2.35876.83844

Folinas, S., \& Metaxas, T. (2020). Tourism: The Great Patient of Coronavirus COVID-2019. International Journal of Advanced Research, 8, 365-375. http://dx.doi.org/10.21474/IJAR01/10788 
Gala, B. (2004). Blogs, Bloggers and Scholarly Publications. In S. Prakashan (Ed.), Library and Information Science: Philosophy and Technology (pp. 204-226). Retrieved from https://www.researchgate.net/publication/340270576

Gössling, S., Scott, D., \& Michael, H. (2020). Pandemics, tourism and global change: a rapid assessment of COVID-19. Journal of Sustainable Tourism, 29(1), 1-20. doi:10.1080/09669582.2020.1758708

Hanna, S., \& Rowley, J. (2008). An analysis of terminology used in place branding. Place Branding and Public Diplomacy, 4, 61-75. https://doi.org/10.1057/palgrave.pb.6000084

Jamal, T., \& Budke, C. (2020). Tourism in a world with pandemics: local-global responsibility and action. Journal of Tourism Futures, 6(2), 181-188. https://doi.org/10.1108/JTF-022020-0014

Johns Hopkins University. (2020). COVID-19 Dashboard by the Center for Systems Science and Engineering (CSSE). Coronavirus Resource Center. Retrieved from https://coronavirus.jhu.edu/map.html?mod=article_inlinehttps://coronavirus.jhu.edu/ma p.html?mod=article_inline

Kelleher, T., \& Miller, B. M. (2006). Organizational Blogs and the Human Voice: Relational Strategies and Relational Outcomes. Journal of Computer-Mediated Communication, 11(2), 395-414. https://doi.org/10.1111/j.1083-6101.2006.00019.x

Kerr, G. (2006). From destination brand to location brand. Brand Management, 13(4/5), 276283. https://doi.org/10.1057/palgrave.bm.2540271

Kirant Yozcu, O., \& Cetin, G. (2019). A Strategic Approach to Managing Risk and Crisis at Tourist Destinations. In N. Kozak \& M. Kozak (Eds.) Tourist Destination Management. Tourism, Hospitality \& Event Management (pp. 273-287). Cham: Springer. https://doi.org/10.1007/978-3-030-16981-7_16

Maheshwari, V., \& Vandewalle, I. (2008). Importance of sustaining place brand identity: a study of Liverpool'08 brand campaign. Paper presented at UneCC Conference, Whose Culture(s)?, Liverpool Hope University, UK, October 16-17, 2008.

Oruonye, E., \& Ahmed, Y. M. (2020). An Appraisal of the Potential Impacts of Covid-19 on Tourism in Nigeria. Journal of Economics and Technology Research, 1(1), 32-40. doi:10.22158/jetr.v1n1p32

Pudliner, B. A. (2007). Alternative literature and tourist experience: Travel and tourist weblogs. Journal of Tourism and Cultural Change, 5(1), 46-59.

Săndulescu, L. (2019). Digital Report 2019. Bucharest: GT.

Sheresheva, M. Y. (2020). Coronavirus and tourism. Population and Economics, 4(2), 72-76. https://doi.org/10.3897/popecon.4.e53574

Tălămbuță, A. (2018). The historical evolution of tourism - general aspects. Law and Life, 8(320), 34-37.

Tudor, R. (2012). Using Travel Blogs to Promote Romania as Tourist Destination. A Comparative Study on Personal Travel Blogs of French and Romanian Travellers. Romanian Journal of Communication and Public Relations, 5, 159-183.

Wang, Y. (2011). Wang, Y. Destination Marketing and Management: Scope, Definition and Structures. In Y. Wang \& A. Pizam, A. (Eds.). Destination marketing and management: Theories and Applications (pp. 1-20). Oxfordshire: CAB International

Wang, Y., \& Morais, D. B. (2014). An examination of tourists' identity in tourist weblogs. Information Technology \& Tourism, 14, 239-260. https://doi.org/10.1007/s40558-0140016-6

Wen, J., Wang, W., Kozak, M., Liu, X., \& Hou, H. (2020). Many brains are better than one: the importance of interdisciplinary studies on COVID-19 in and beyond tourism. Tourism Recreation Research. https://doi.org/10.1080/02508281.2020.1761120 
World Tourism Organization (UNWTO). (2020). STAY HOME TODAY, \#TRAVELTOMORROW. Retrieved from https://www.unwto.org/news/stay-home-todaytraveltomorrow 